\title{
Structure of services and material health resources associated with the School Health Program
}

\author{
Estrutura dos serviços e recursos materiais em saúde associados ao Programa Saúde na Escola \\ Estructura de servicios y recursos materiales en salud asociados al Programa Salud en la Escuela
}

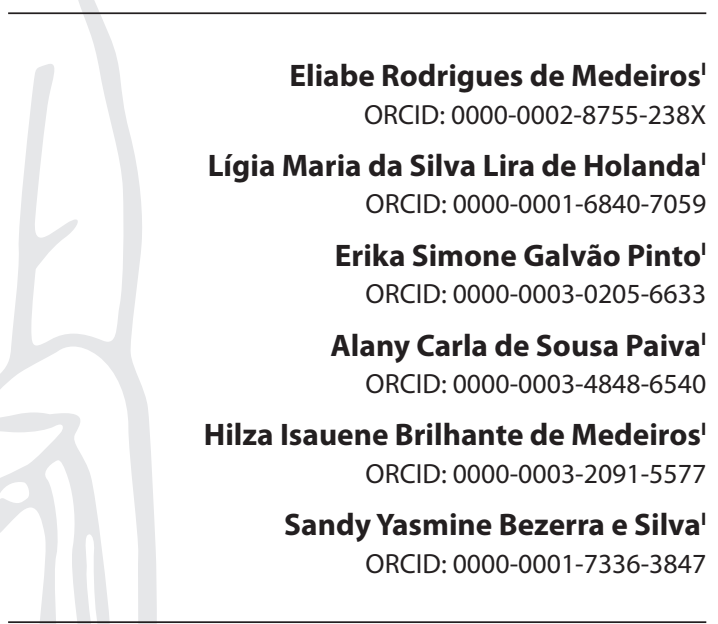

'Universidade Federal do Rio Grande do Norte. Natal, Rio Grande do Norte, Brazil.

How to cite this article: Medeiros ER, Holanda LMSL, Pinto ESG, Paiva ACS, Medeiros HIB, Bezerra e Silva SY. Structure of services and material health resources associated with the School Health Program. Rev Bras Enferm. 2020;73(6):e20190073. doi: http://dx.doi.org/10.1590/0034-7167-2019-0073

Corresponding author: Eliabe Rodrigues de Medeiros E-mail: eliabe.medeiros@hotmail.com

EDITOR IN CHIEF: Dulce Barbosa ASSOCIATE EDITOR: Mitzy Reichembach

Submission: 03-13-2019

Approval: 02-23-2020

\begin{abstract}
Objectives: to describe the structure used in the School Health Program and analyze the association between its material resources and the actions carried out. Methods: cross-sectional, quantitative, analytical, and normative study. A normative instrument of the program was applied to collect data from May to July 2017 with 105 Family Health Strategy professionals. Data were organized and analyzed using descriptive and inferential statistics on IBM SPSS Statistics 22.0 software. Results: financial resources were made available with low periodicity; the most used human resources were dentists; the most frequent infrastructure resource was the school; the most frequently used materials were those related to administrative support (legal-size paper and pen) and clinical resources (fluoride, toothbrush, and toothpaste). An association was identified between resources and anthropometric assessment activities and vaccination status. Conclusions: the program structure showed reduced financial resources and priority participation of human resources from the health sector, and the actions were carried out by using the school infrastructure and administrative and clinical materials. Descriptors: School Health Services; Financial Resources in Health; Health Workforce; Structure of Services; Material Resources in Health.
\end{abstract}

\section{RESUMO}

Objetivos: descrever a estrutura utilizada no Programa Saúde na Escola e analisar a associação entre os recursos materiais e as ações desenvolvidas. Métodos: estudo transversal, quantitativo, analítico e normativo. Utilizou-se o instrumento normativo do programa para coletar dados de maio a julho de 2017, com 105 profissionais da Estratégia Saúde da Família. Os dados foram organizados e analisados de forma descritiva e inferencial no IBM SPSS Statistics 22.0. Resultados: foi observada baixa frequência de recursos financeiros; os recursos humanos mais utilizados foram odontólogos; o recurso infraestrutural mais frequente foi a escola; os materiais mais frequentemente utilizados foram de apoio administrativo (papel ofício e caneta) e clínicos (flúor, escova e creme dental). Identificou-se associação entre recursos e atividades de avaliação antropométrica e situação vacinal, por exemplo. Conclusões: a estrutura do programa detém recursos financeiros reduzidos, participação prioritária de recursos humanos do setor saúde, e suas ações são desenvolvidas na infraestrutura escolar, com materiais administrativos e clínicos.

Descritores: Serviços de Saúde Escolar; Recursos Financeiros em Saúde; Mão de Obra em Saúde; Estrutura dos Serviços; Recursos Materiais em Saúde.

\section{RESUMEN}

Objetivos: describir la estructura utilizada en el Programa Salud en la Escuela y analizar la asociación entre recursos materiales y acciones desarrolladas. Métodos: estudio transversal, cuantitativo, analítico y normativo. Se aplicó instrumento normativo del programa para recolectar datos de mayo a julio de 2017, con 105 profesionales de Estrategia Salud de la Familia, organizados y analizados descriptiva e inferencialmente con IBM SPSS Statistics 22.0. Resultados: se observó baja frecuencia de recursos financieros; los recursos humanos más utilizados fueron odontólogos; el recurso de infraestructura más habitual fue la escuela; el material de uso más frecuente fue de apoyo administrativo (papel oficio y bolígrafo) y clínico (flúor, cepillo y dentífrico). Se identificó asociación entre recursos y actividades de evaluación antropométrica y situación vacunal, por ejemplo. Conclusiones: la estructura del programa recibe recursos financieros escasos, participación prioritaria de recursos humanos del sector salud, en infraestructura escolar y con material administrativo y clínico.

Descriptores: Servicios de Salud Escolar; Recursos Financieros en Salud; Fuerza Laboral en Salud; Estructura de los Servicios; Recursos Materiales en Salud. 


\section{INTRODUCTION}

Health interventions oriented toward educational spaces are important strategies to promote health and can considerably affect the quality of life and well-being of the school community ${ }^{(1)}$. The origin of these proposals is deep-seated in the influence of the Health Promoting Schools movement, created by the World Health Organization in the 1990s. It proposed a change in the system, with the integration of the health and education sectors, the establishment of adequate settings, and the effective participation of the school community ${ }^{(2-3)}$.

The execution of these intersectoral actions has proved important when it is considered that children enrollment rate in primary and high schools worldwide has increased in the past few years, reaching values over $90 \%$ and $80 \%$, respectively ${ }^{(4-5)}$. From another perspective, it is known that several risk factors can compromise the health of children and adolescents at school age, including malnutrition and overweight, smoking, consumption of alcohol, inadequate eating habits, and a sedentary lifestyle, which can lead to the development of chronic noncommunicable diseases ${ }^{(6)}$.

The main Brazilian intervention oriented toward school health was created in 2007 and entitled School Health Program. Its goal is carrying out health activities in primary education institutions to meet the health needs of the people who are part of this environment. The program's normative instruction proposes that it be implemented by carrying out activities organized into three components: Component I, referring to clinical and psychosocial actions; Component II, referring to actions designed to promote and prevent diseases and health problems; and Component III, referring to actions to train professionals so they can carry out the activities listed in Components I and II(7).

Operationalizing these actions requires that the resources intended to subsidize the planning and execution of the program's proposals are made available and transferred ${ }^{(8)}$. When properly managed and transferred in enough amounts by the governmental sphere, these resources can influence the implementation of health policies ${ }^{(9)}$, such as the School Health Program, which may impact the quality of life of the population they are oriented toward ${ }^{(10)}$.

Although financial and structural resources are necessary, their scarceness has been one of the difficulties to implement the program, and having them available can be considered a factor that increases the chances of a school health intervention to be success$\mathrm{ful}^{(11)}$. Resource availability has been one of the ways to contribute to changing habits toward a healthier lifestyle among students ${ }^{(12)}$.

Given that the structural difficulties and needs of the School Health Program are known and that it is a national intervention, it is necessary to examine the availability of the resources intended for the operationalization of this program. The authors developed their reasoning based on the comprehension that if there is an offer of structure and material resources, there is an influence on the execution of the actions proposed by the program.

\section{OBJECTIVES}

To describe the structure used in the School Health Program and analyze the association between material resources and actions carried out.

\section{METHODS}

\section{Ethical aspects}

The present study complied with international and Brazilian ethical principles involved in human research. The Research Ethics Committee at the Federal University of Rio Grande do Norte evaluated the study proposal and its adequacy to the recommendations of the Brazilian National Health Council Resolution $466 / 2012$. The board members approved the execution of the study as per report no. 2,064,901 and Certificate of Presentation for Ethical Appreciation no. 64873916.1.0000.5537. The participants were informed about the risks and benefits resulting from being part of the study sample and signed free and informed consent forms after agreeing to contribute to the study.

\section{Study design, location, and period}

This was a cross-sectional, quantitative, analytical, and normative study.

Normative studies are carried out by comparing what is proposed in the recommendations of a program and the availability of these in its operationalization ${ }^{(13)}$.

Manuscript writing followed the guidelines proposed in the Strengthening the Reporting of Observational Studies in Epidemiology statement ${ }^{(14)}$.

The study was carried out at Family Health Units (FHUs) in the municipality of Natal, capital of the state of Rio Grande do Norte, Brazil. The estimated population of this city is over 800 thousand people, who have their health needs met by the Brazilian Unified Health System at 79 facilities, among which 38 are FHUs (used as the study setting), distributed over five health districts (South, East, West, North I, and North II) ${ }^{(15-16)}$.

The study was carried out between May and July 2017.

\section{Population, sample, and inclusion and exclusion criteria}

There was neither information about the number of professionals who carried out school health activities nor a list with their names during the study execution period. It was a consensus that each FHU in the municipality would have a professional responsible for carrying out activities with their team.

Therefore, for the participant selection process, it was considered that each of the 38 FHUs should have at least one family health team, made up of a physician, a nurse, a nursing technician or aide, a community health worker, a dentist, and an oral health technician or aide, which made up a group of 228 professionals.

Based on sample calculation for finite populations and applying a 95\% confidence interval and a 5\% sampling error, it was established that 144 professionals of that group should make up the study sample. It was decided that data collection would be performed with six participants from different professions at each FHU to guarantee that the sample would include similar numbers of professionals from different categories.

Dividing 144 professionals by six (the number of categories that compose FHU teams) resulted in the definition of the number of 28 FHUs to be included in the study sample and visited for 
data collection. The units were selected by making a draw. If the drawn unit did not have a professional that carried out School Health Program activities, another FHU was drawn.

The inclusion criterion for Family Health Strategy professionals was having carried out activities of the examined program previously. Professionals who were not developing their professional activities for being on vacation or leave of any kind were excluded.

The study was performed with 105 out of the 144 professionals that sample calculation indicated. This occurred because in some FHUs only a few drawn professionals carried out School Health Program activities. During the visits to FHUs for data collection, 28 professionals declared that they did not carry out the program's actions even having a member of their team included in these activities, seven refused to participate in the study, and four were away from their functions. The authors opted to not replace these professionals with members from other categories so data would have better representativeness regarding the different professional classes existing in FHUs.

\section{Study protocol}

Data were collected by applying an instrument whose development was based on the norms that guide the execution of the School Health Program. The description of the program's structure took into account financial, human, infrastructural, and material resources recommended to carry out primary health care activities, including school health ones, listed in the Self-evaluation for Access and Quality Improvement of Primary Care instruments ${ }^{(17)}$. In the context of the present study, structure is defined as human, material, organizational, and physical resources necessary for providing health care ${ }^{(18)}$.

The questions were grouped into categories addressing professional characterization and structure dimension, and the presence or absence of items in each category could be indicated by the participants. Question adaptation was carried out by five professionals with experience in the education and school health care fields who were not part of the sample.

Data collection was performed by four nurses and four nursing undergraduate students. They were submitted to training and received guidance on the procedures of that step of the study.

\section{Results analysis and statistics}

Data were typed on IBM SPSS Statistics 22.0 spreadsheets. This software was used to treat data with descriptive and inferential statistics and create tables showing absolute and relative numbers. Inferential statistics procedures included Pearson's chi-squared test and Fisher's exact test.

Initially, the resources used by the professionals were identified, and were analyzed in a subsequent step according to the list of activities in Components I and II of the School Health Program ${ }^{(7)}$.

\section{RESULTS}

The participants who made up the sample were physicians (5.7\%), nurses (19.0\%), nursing technicians or aides (12.4\%), community health workers (22.9\%), dentists (21.0\%), and oral health technicians or aides (19.0\%). Women prevailed in the sample (84.8\%), and the most frequent levels of education were: technical training (31.4\%), specialization (26.7\%), and graduate degree (19.0\%).
Table 1 - Characterization of the human resources used in the School Health Program, Natal, Rio Grande do Norte, Brazil, 2017

\begin{tabular}{lcc}
\hline Human resources* & N & $\%$ \\
\hline Dentists & 100 & 95.2 \\
Community health workers & 96 & 91.4 \\
Oral health technicians or aides & 89 & 84.8 \\
Nurses & 83 & 79.0 \\
Nursing technicians or aides & 78 & 74.3 \\
Physicians & 59 & 56.2 \\
Teachers & 54 & 51.4 \\
School managers & 44 & 41.9 \\
Family health unit managers & 29 & 27.6 \\
Undergraduate students & 10 & 9.5 \\
Pedagogical coordinators & 7 & 6.6 \\
Invited professionals & 4 & 3.8 \\
Support staff & 1 & 0.9 \\
\hline
\end{tabular}

Note: *The sum exceeds 100\% because the participants could mention more than one variable.

Table 2 - Characterization of the infrastructure resources used in the School Health Program, Natal, Rio Grande do Norte, Brazil, 2017

\begin{tabular}{lcc}
\hline Infrastructure resources* & $\mathbf{n}$ & $\%$ \\
\hline Schools & 105 & 100.0 \\
Nongovernmental organizations & 8 & 7.6 \\
Religious institutions & 7 & 6.7 \\
Health units & 4 & 3.8 \\
Multisport gyms & 3 & 2.9 \\
Councils & 2 & 1.9 \\
\hline Note: *The sum exceeds 100\% because the participants could mention more than one variable.
\end{tabular}

Table 3 - Characterization of the material resources used in the School Health Program, Natal, Rio Grande do Norte, Brazil, 2017

\begin{tabular}{|c|c|c|}
\hline Material resources* & $\mathbf{N}$ & $\%$ \\
\hline Legal-size paper & 63 & 60.0 \\
\hline Pens & 62 & 59.0 \\
\hline Toothpaste & 59 & 56.2 \\
\hline Toothbrushes & 59 & 56.2 \\
\hline Fluoride & 57 & 54.3 \\
\hline Gloves & 55 & 52.4 \\
\hline Educational materials & 48 & 45.7 \\
\hline Pencils & 47 & 44.8 \\
\hline Anthropometric scales & 42 & 40.0 \\
\hline Measuring tapes & 42 & 40.0 \\
\hline Demonstrative materials & 36 & 34.3 \\
\hline Instructive materials & 33 & 31.4 \\
\hline Stethoscopes & 32 & 30.5 \\
\hline Sphygmomanometers & 32 & 30.5 \\
\hline Folders & 32 & 30.5 \\
\hline Needles & 28 & 26.7 \\
\hline Cotton balls & 28 & 26.7 \\
\hline Colored pencils & 27 & 25.7 \\
\hline Card stock paper & 26 & 24.8 \\
\hline Anthropometric rulers & 25 & 23.8 \\
\hline Other materials & 25 & 23.8 \\
\hline Immunobiologics & 22 & 21.0 \\
\hline Syringes & 22 & 21.0 \\
\hline Medications & 16 & 15.2 \\
\hline Condoms & 16 & 15.2 \\
\hline Personal protective equipment & 13 & 12.4 \\
\hline Macromodel kits & 12 & 11.4 \\
\hline Clinical torches & 8 & 7.6 \\
\hline Projectors & 8 & 7.6 \\
\hline Glucometers & 4 & 3.8 \\
\hline Otoscopes & 2 & 1.9 \\
\hline Spoons & 2 & 1.9 \\
\hline
\end{tabular}


Table 4 - Characterization of the association between material resources and Component I activities advocated by the School Health Program, Natal, Rio Grande do Norte, Brazil, 2017

\begin{tabular}{|c|c|c|c|c|}
\hline \multirow[b]{2}{*}{ Material resources } & \multicolumn{3}{|c|}{ Component I activities } & \multirow[b]{2}{*}{$\stackrel{p}{p}$} \\
\hline & $\begin{array}{l}\text { Yes } \\
\text { n (\%) }\end{array}$ & $\begin{array}{c}\text { No } \\
\text { n (\%) }\end{array}$ & $\begin{array}{l}\text { Total } \\
\text { N (\%) }\end{array}$ & \\
\hline \multicolumn{5}{|l|}{ Anthropometric evaluation } \\
\hline Anthropometric scales & $37(98.1)$ & $5(11.9)$ & $42(100.0)$ & $<0.001$ \\
\hline Anthropometric rulers & $25(100.0)$ & - & $25(100.0)$ & $<0.001$ \\
\hline Measuring tapes & $34(81.0)$ & $8(19.0)$ & $42(100.0)$ & $<0.001$ \\
\hline Instructive materials & $18(54.5)$ & $15(45.5)$ & $33(100.0)$ & 0.028 \\
\hline \multicolumn{5}{|c|}{ Vaccination status evaluation } \\
\hline Immunobiologics & $21(95.5)$ & $1(4.5)$ & $22(100.0)$ & $<0.001$ \\
\hline Syringes & $21(95.5)$ & $1(4.5)$ & $22(100.0)$ & $<0.001$ \\
\hline Needles & $21(95.5)$ & $1(4.5)$ & $22(100.0)$ & $<0.001$ \\
\hline Gloves & $19(34.5)$ & $36(65.5)$ & $55(100.0)$ & 0.876 \\
\hline Cotton balls & $26(92.9)$ & $2(7.1)$ & $28(100.0)$ & $<0.001$ \\
\hline Instructive materials & $17(51.5)$ & $16(48.5)$ & $33(100.0)$ & 0.018 \\
\hline \multicolumn{5}{|l|}{$\begin{array}{l}\text { Early detection of chronic } \\
\text { diseases }\end{array}$} \\
\hline Medications & $8(50.0)$ & $8(50.0)$ & $16(100.0)$ & 0.005 \\
\hline Folders & $6(18.8)$ & $26(81.3)$ & $32(100.0)$ & 0.507 \\
\hline Immunobiologics & $12(54.5)$ & $10(45.5)$ & $22(100.0)$ & $<0.001$ \\
\hline Instructive materials & $7(21.2)$ & $26(78.8)$ & $33(100.0)$ & 0.786 \\
\hline Educational materials & $9(18.8)$ & 39 (81.3) & $48(100.0)$ & 0.358 \\
\hline Sphygmomanometers & $16(50.0)$ & $16(50.0)$ & $32(100.0)$ & $<0.001$ \\
\hline \multicolumn{5}{|l|}{$\begin{array}{l}\text { Early detection of neglected } \\
\text { diseases }\end{array}$} \\
\hline Medications & $8(50.0)$ & $8(50.0)$ & $16(100.0)$ & $<0.001$ \\
\hline Folders & $6(18.8)$ & $26(81.3)$ & $32(100.0)$ & 0.190 \\
\hline Immunobiologics & $6(27.3)$ & $16(72.7)$ & $22(100.0)$ & 0.017 \\
\hline Sphygmomanometers & $8(25.0)$ & $24(75.0)$ & $32(100.0)$ & 0.009 \\
\hline Instructive materials & $8(24.2)$ & $25(75.8)$ & $33(100.0)$ & 0.012 \\
\hline Educational materials & $8(16.7)$ & $40(83.3)$ & $48(100.0)$ & 0.221 \\
\hline \multicolumn{5}{|l|}{ Ophthalmologic evaluation } \\
\hline Clinical torches & $1(12.5)$ & $7(87.5)$ & $8(100.0)$ & 0.213 \\
\hline Stethoscopes & $3(9.4)$ & $29(90.6)$ & $32(100.0)$ & 0.026 \\
\hline Otoscopes & $1(50.0)$ & $1(50.0)$ & $2(100.0)$ & 0.057 \\
\hline Spoons & $1(50.0)$ & $1(50.0)$ & $2(100.0)$ & 0.199 \\
\hline Instructive materials & $3(9.1)$ & $30(90.9)$ & $33(100.0)$ & 1.000 \\
\hline \multicolumn{5}{|l|}{ Nutritional evaluation } \\
\hline Anthropometric scales & $5(11.9)$ & $37(88.1)$ & $42(100.0)$ & 0.262 \\
\hline Anthropometric rulers & $5(20.0)$ & $20(80.0)$ & $25(100.0)$ & 0.018 \\
\hline Measuring tapes & $5(11.9)$ & $37(88.1)$ & $42(100.0)$ & 0.262 \\
\hline Glucometers & $1(25.0)$ & $3(75.0)$ & $4(100.0)$ & 0.275 \\
\hline Stethoscopes & $5(15.6)$ & $27(84.4)$ & $32(100.0)$ & 0.054 \\
\hline Sphygmomanometers & $5(15.6)$ & $27(84.4)$ & $32(100.0)$ & 0.054 \\
\hline Instructive materials & $2(6.1)$ & $31(93.9)$ & $33(100.0)$ & 1.000 \\
\hline \multicolumn{5}{|l|}{ Oral health evaluation } \\
\hline Fluoride & $46(80.7)$ & $11(10.3)$ & $57(100.0)$ & $<0.001$ \\
\hline Toothpaste & $47(79.7)$ & $12(20.3)$ & $59(100.0)$ & $<0.001$ \\
\hline Toothbrushes & 47 (79.7) & $12(20.3)$ & $59(100.0)$ & $<0.001$ \\
\hline Instructive materials & $17(51.5)$ & $16(48.5)$ & $33(100.0)$ & 1.000 \\
\hline Colored pencils & $17(63.0)$ & $10(37.0)$ & $27(100.0)$ & 1.000 \\
\hline Card stock paper & $13(50.0)$ & $13(50.0)$ & $26(100.0)$ & 0.955 \\
\hline Legal-size paper & $35(55.6)$ & $28(44.4)$ & $63(100.0)$ & 0.202 \\
\hline \multicolumn{5}{|l|}{ Hearing evaluation } \\
\hline Instructive materials & $1(3.0)$ & $32(97.0)$ & $33(100.0)$ & 1.000 \\
\hline Otoscopes & $1(50.0)$ & $1(50.0)$ & $2(100.0)$ & 0.057 \\
\hline Clinical torches & $1(12.5)$ & $7(87.5)$ & $8(100.0)$ & 0.213 \\
\hline \multicolumn{5}{|l|}{ Psychosocial evaluation } \\
\hline Instructive materials & $1(3.0)$ & $32(97.0)$ & $33(100.0)$ & 0.314 \\
\hline Folders & - & $32(100.0)$ & ) $32(100.0)$ & 1.000 \\
\hline Pens & $1(1.6)$ & $61(98.4)$ & $62(100.0)$ & 1.000 \\
\hline Colored pencils & $1(3.7)$ & $26(96.3)$ & $27(100.0)$ & 0.257 \\
\hline Pencils & $1(2.1)$ & $46(97.9)$ & $47(100.0)$ & 0.448 \\
\hline Legal-size paper & $1(1.6)$ & $62(98.4)$ & $63(100.0)$ & 1.000 \\
\hline Card stock paper & $1(3.8)$ & $25(96.2)$ & $26(100.0)$ & 0.248 \\
\hline
\end{tabular}

Note: *Pearson's chi-squared test or Fisher's exact test.
Table 5 - Characterization of the association between material resources and Component II activities advocated by the School Health Program, Natal, Rio Grande do Norte, Brazil, 2017

\begin{tabular}{|c|c|c|c|c|}
\hline \multirow[b]{2}{*}{ Material resources } & \multicolumn{3}{|c|}{ Component II activities } & \multirow{2}{*}{$\underset{\text { value* }}{p}$} \\
\hline & $\begin{array}{c}\text { Yes } \\
\text { n (\%) }\end{array}$ & $\begin{array}{c}\text { No } \\
\text { n (\%) }\end{array}$ & $\begin{array}{l}\text { Total } \\
\text { N (\%) }\end{array}$ & \\
\hline
\end{tabular}

Promotion of healthy eating habits

and food safety

Macromodel kits

Personal protective equipment

Instructive materials

$2(16.7) \quad 10(83.3) \quad 12(100.0) \quad 0.729$

$1(7.7) \quad 12(92.3) \quad 13(100.0) \quad 0.289$

$11(33.3) 22(66.7) 33(100.0) \quad 0.083$

Promotion of sexual and reproductive health and prevention of sexually

transmissible infections/AIDS

Condoms

Instructive materials

Demonstrative materials

Folders

Promotion of body practices and

physical activities

Educative materials

Folders

Demonstrative materials

Pens

Colored pencils

Pencils

Legal-size paper

Card stock paper

Prevention of use of alcohol,

tobacco, crack, and other drugs

Demonstrative materials

Educational materials

Folders

Pens

Pencils

Colored pencils

Legal-size paper

Card stock paper

$13(81.3) \quad 3(18.8) \quad 16(100.0)<0.001$ $18(54.5) \quad 15(45.5) \quad 33(100.0) \quad 0.001$ $19(52.8) \quad 17(42.2) \quad 36(100.0) \quad 0.001$ 15 (46.9) $17(53.1) \quad 32(100.0) \quad 0.024$

$3(6.3) \quad 45(93.8) \quad 48(100.0) \quad 0.658$ $1(3.1) \quad 31(96.9) \quad 32(100.0) \quad 1.000$ 2 (5.6) $34(94.4) \quad 36(100.0) \quad 1.000$ $5(8.1) \quad 57(91.9) \quad 62(100.0) \quad 0.077$ $2(7.4) \quad 25(92.6) \quad 27(100.0) \quad 0.601$ $4(8.5) \quad 43(91.5) \quad 47(100.0) \quad 0.170$ $2(3.2) \quad 61(96.8) \quad 63(100.0) \quad 0.387$ $3(11.5) \quad 23(88.5) \quad 26(100.0) \quad 0.096$

$10(27.8) 26(72.2) \quad 36(100.0) \quad 0.037$ $11(22.9) \quad 37(77.1) \quad 48(100.0) \quad 0.150$ $8(25.0) \quad 24(75.0) \quad 32(100.0) \quad 0.170$ $11(17.7) 51(82.3) 62(100.0) 1.000$ $11(23.4) \quad 36(76.6) \quad 47(100.0) \quad 0.125$ $10(37.0) 17(63.0) 27(100.0) \quad 0.001$ 15 (23.8) 48 (76.2) $63(100.0) \quad 0.034$ $10(38.5) \quad 16(61.5) \quad 26(100.0) \quad 0.001$

Promotion of culture of peace and human rights

Educational materials

Folders

Demonstrative materials

Pens

Colored pencils

Pencils

Legal-size paper

Card stock paper

Prevention of violence and accidents

Colored pencils

Legal-size paper

Card stock paper

Educational materials

Demonstrative materials

Folders

$3(6.3) \quad 45(93.8) \quad 48(100.0) \quad 0.658$

$\begin{array}{llll}2(6.3) & 30(93.8) & 32(100.0) & 0.639\end{array}$

$\begin{array}{llll}3(8.3) & 33(91.7) & 36(100.0) & 0.336\end{array}$

$\begin{array}{llll}5(8.1) & 57(91.9) & 62(100.0) & 0.077\end{array}$

$3(11.1) \quad 24(88.9) \quad 27(100.0) \quad 0.106$

$3(6.4) \quad 44(93.6) \quad 47(100.0) \quad 0.655$

$2(3.2) \quad 61(96.8) \quad 63(100.0) \quad 0.387$

$3(11.5) \quad 23(88.5) \quad 26(100.0) \quad 0.096$

Promotion of environmental health and sustainable development

Colored pencils

Legal-size paper

Card stock paper

Educational materials

Demonstrative materials

Folders

Note: *Pearson's chi-squared test or Fisher's exact test. $\begin{array}{llll}5(18.5) & 22(81.5) & 27(100.0) & 0.261\end{array}$ $9(14.3) \quad 54(85.7) \quad 63(100.0) \quad 0.556$ $6(23.1) \quad 20(76.9) \quad 26(100.0) \quad 0.056$ $8(16.7) \quad 40(83.3) \quad 48(100.0) \quad 0.221$ $8(22.2) \quad 28(77.8) \quad 36(100.0) \quad 0.027$ $4(12.5) \quad 28(87.5) \quad 32(100.0) \quad 1.000$

$4(14.8) \quad 23(85.2) \quad 27(100.0) \quad 0.468$ $7(11.1) \quad 56(88.9) \quad 63(100.0) \quad 1.000$ $7(26.9) \quad 19(73.1) \quad 26(100.0) \quad 0.005$ $8(16.7) \quad 40(83.3) \quad 48(100.0) \quad 0.106$ $6(16.7) \quad 30(83.3) \quad 36(100.0) \quad 0.135$ $3(9.4) \quad 29(90.6) \quad 32(100.0) \quad 1.000$ 
The answers of the participants allowed to identify the School Health Program structure. The first identified item was the existence of financial resources. Among the 105 professionals in the sample, $16.2 \%$ declared that resources were made available to carry out the program's activities. These resources can be transferred to professionals directly or the municipal government, which coordinates the expenses with the program execution.

Data related to the human resources used in the School Health Program are shown in Table 1.

The results in Table 1 indicated the presence of a higher number of professionals who carry out technical activities, such as the professionals that made up the oral health and nursing teams. Additionally, there was the contribution of people from other areas, for instance teachers, who play an important role in the educational sector, as well as the administrative staff and undergraduate students.

Data related to the infrastructure resources used to carry out the program's activities are shown in Table 2.

The higher frequency of used settings was observed for schools (100\%). In contrast, the other community resources were used by professionals with a lower frequency, as exemplified by nongovernmental organizations (7.6\%).

The material resources used by Family Health Strategy professionals in the operationalization of the School Health Program are shown in Table 3.

The results related to material resources indicated that there was a higher frequency of objects used to support administrative activities and those intended for the activities carried out by oral health teams.

Because of that, material resources data were submitted to statistical analysis taking into account the actions mentioned in Component I advocated in the norms of the School Health Program. The results of this analysis are shown in Table 4.

Data allowed to identify that there was a stronger statistical association between some material resources and activities related to anthropometric assessment, vaccination status, early detection of chronic diseases, early detection of neglected diseases, and oral health evaluation.

The statistical association between material resources and Component II actions was also analyzed. These results are shown in Table 5.

Data indicated that there was a statistical association between some of the material resources and activities to promote sexual and reproductive health and prevention of sexually transmissible infections/AIDS, as well as activities to prevent use of alcohol, tobacco, crack, and other drugs.

\section{DISCUSSION}

The findings of the present study showed availability of financial resources, prevalence of human resources from the health sector, prevailing use of schools as infrastructure resources, and more frequent use of material resources that support administrative tasks or clinical and psychosocial assessment activities.

The use of financial resources in the School Health Program identified in other studies carried out in the metropolitan area of the city of Salvador, the Brazilian Northeast region, and Portugal has been similar to that found in the present study ${ }^{(19-20)}$. These studies pointed out that the available resources can hinder the implementation of health actions oriented toward students. By considering that funding availability contributes to implementing these activities ${ }^{(21)}$, the results of the present study regarding financial resources may negatively influence the monitoring of the health condition of students. It is important to stress that these resources are directly transferred to the program management team, which must use them in ways that contribute to the actions to be carried out.

For the advocated activities to be performed effectively, the conjoint participation of health professionals and the staff that works at school is necessary ${ }^{(8)}$, as pointed out by a study carried out in Canada ${ }^{(21)}$. This study stressed the importance of the participation of principals, teachers, and other school employees for the onset of the activities of a school health service ${ }^{(21)}$. However, this study showed a different characteristic regarding human resources. There was greater participation of professionals from the health sector, such as dentists, community health workers, oral health technicians or aides, and nurses. The presence of teachers and other categories or agents was identified in the execution of the program, even if in smaller proportions.

Regarding infrastructure resources, the school setting was the most used to carry out the program's activities, which corroborated the findings of a study that mentioned the school environment as the main responsible for promoting health actions at the school level(22). Nevertheless, it is important that School Health Program actions be expanded to other infrastructure settings in the community where they are carried out to strengthen the partnerships with other institutions.

Regarding material resources, it was observed that most of the objects were used in administrative (legal-size paper, pens, pencils) and dental activities (toothpaste, toothbrushes, fluoride). Most of the materials necessary to plan and execute the activities were available, although in reduced quantities. This find corroborated the results of a study that indicated the presence of materials considered essential for the execution of school health services ${ }^{(23)}$.

The materials made available in programs oriented toward school health contribute to improving knowledge and healthy practices among students ${ }^{(24-25)}$. This was exemplified by a study carried out in Nepal, which showed that material availability helped implement the proposed activities ${ }^{(26)}$.

It is important to consider that monitoring the needs related to these materials in the program execution is an important strategy to adjust the transfer of resources according to the real demands of the places where the activities are carried out. This point was emphasized by a study performed in Iran, which pointed out that material availability must be corrected in school health interventions to guarantee the proper implementation of the school health program ${ }^{(27)}$.

Measuring tapes and anthropometric scales and rulers showed a statistical association with anthropometric evaluation activities. This result stresses the importance of making these resources available at schools because they are indispensable for monitoring students' weight and height as a way to keep track of their health condition ${ }^{(28)}$. 
Vaccination status activities showed a statistical association with the following material resources: immunobiologics, syringes, needles, and cotton balls. These materials are important to update the vaccination status of children and adolescents whose vaccination status is incomplete to reduce the occurrence of vaccine-preventable diseases.

Another important aspect that these resources allow is increasing vaccination coverage based on activities carried out at the school setting. It must be emphasized that an increase in vaccination coverage can be triggered by health education strategies and integration between health services ${ }^{(29)}$, and both these activities have the potential to be carried out in the School Health Program context.

Regarding the statistical association found between oral health evaluation activities and the presence of the material resources fluoride, toothpaste, and toothbrushes, a study carried out in the Brazilian state of São Paulo applied these and other resources to perform oral health activities at school that proved effective in improving toothbrushing practices and developing healthy habits ${ }^{(30)}$.

Instructive and demonstrative materials, folders, colored pencils, legal-size paper, and card stock paper were material resources that showed a statistical association with both Component I (early detection of chronic and neglected diseases) and Component II (promotion of sexual and reproductive health, prevention of sexually transmissible infections/AIDS, and prevention of use of alcohol, tobacco, crack, and other drugs) activities.

Using these resources is important to guide professionals on how to carry out the program's activities (instructive materials) and to help them implement the actions, when they share information with students by means of folders and demonstrative materials. This contributed to increasing the effectiveness of the activities, as exemplified by a study carried out in Germany, in which the interventions that involved the use of educational materials effectively contributed to promoting behaviors and were associated with the improvement of students' health ${ }^{(31)}$.

\section{Study limitations}

The present study had some characteristics that can be considered limitations: the use of a single source for data collection and the fact that the population and the sample were health professionals only. The latter limitation can be justified by the predominance of health professionals over education ones in the Brazilian context.

Additionally, it was not possible to keep proportionality in the professional categories in the final sample even though equal participation of the six professions included in the study was advocated for the sampling process.

\section{Contributions to the nursing, health, or public policy area}

The results of the present study allow to understand the importance of managing the resources of the School Health Program based on the needs of the place where it is carried out. To do that, managers have to be committed to offer support and transfer financial resources in adequate amounts to meet the demands of each school, especially regarding the materials identified as showing a statistical association with the planning and execution of activities of professionals who make up health and education teams, including nurses.

\section{CONCLUSIONS}

The structure of the School Health Program had a reduced amount of financial resources, showed a prevailing participation of human resources from the health sector, had schools as the most used infrastructure resource, and showed a prevalence of material resources applied to carry out administrative support and clinical activities.

It was identified that some materials showed a statistical association with activities advocated by the program. For instance, measuring tapes and anthropometric scales and rulers had an association with anthropometric evaluation activities; immunobiologics, syringes, needles, and cotton balls showed an association with vaccination status evaluation activities; fluoride, toothpaste, and toothbrushes had an association with oral health evaluation activities; and instructive and demonstrative materials, folders, colored pencils, legal-size paper, and card stock paper showed an association with activities related to early detection of chronic and neglected diseases, promotion of sexual and reproductive health, prevention of sexually transmissible diseases/AIDS, and prevention of use of alcohol, tobacco, crack, and other drugs.

It is suggested that other studies on the structure of the School Health Program be carried out with a higher number of data sources to make the results more consistent. Consequently, the authors encourage the execution of studies that apply data triangulation after data collection with professionals from the health and education sector, secondary data extracted from information and monitoring systems, and documental data sources such as record books, which are commonly used by professionals who work at the School Health Program.

\section{FUNDING}

The present study was funded by the Brazilian National Council for Scientific and Technological Development by means of a master's scholarship.

\section{REFERENCES}

1. Bezerra MKA, Carvalho EMF, Oliveira JS, Cesse EAP, Lira PIC, Cavalcante JGT, et al. Health promotion initiatives at school related to overweight, insulin resistance, hypertension and dyslipidemia in adolescents: a cross-sectional study in Recife, Brazil. BMC Public Health. 2018;18:223. doi: 10.1186/s12889-018-5121-6

2. Turunen H, Sormunen M, Jourdan D, Seelen JV, Buijs G. Health Promoting Schools - a complex approach and a major means to health improvement. Health Promot Int. 2017;32(2):177-84. doi: 10.1093/heapro/dax001 
3. Littlecott HJ, Long S, Hawkins J, Murphy S, Hewitt G, Eccles G, et al. Health Improvement and Educational Attainment in Secondary Schools: Complementary or Competing Priorities? Exploratory Analyses From the School Health Research Network in Wales. Health Educ Behav. 2018;45(4):635-44. doi: 10.1177/1090198117747659

4. United Nations Children's Fund (UNICEF). UNICEF Data: Monitoring the situation of children and women. Primary education [Internet]. New York (NY): UNICEF; 2019 [cited 2020 Feb 23]. Available from: https://data.unicef.org/topic/education/primary-education/

5. United Nations Children's Fund (UNICEF). UNICEF Data: Monitoring the situation of children and women. Secondary Education [Internet]. New York (NY): UNICEF; 2019[cited 2020 Feb 23]. Available from: https://data.unicef.org/topic/education/secondary-education/

6. World Health Organization. Health Promoting School: an effective approach for early action on NCD risk factors [Internet]. WHO; 2017[cited 2019 Feb 03]. Available from: http://apps.who.int/iris/bitstream/10665/255625/1/WHO-NMH-PND-17.3-eng.pdf?ua=1

7. Ministério da Saúde (BR). Ministério da Educação. Caderno do gestor do PSE [Internet]. Brasília (DF): Ministério da Saúde; 2015 [cited 2020 Feb 21], 68 p. Available from: http://bvsms.saude.gov.br/bvs/publicacoes/caderno_gestor_pse.pdf

8. Penso MA, Brasil KCTR, Arrais AR, Lordello SR. Health and school: perceptions of this relationship by primary health care professionals working with teenagers in the Federal District. Saúde Soc. 2013;22(2):542-53. doi: 10.1590/S0104-12902013000200023

9. Christmann M, Pavão SMO. Health of school children cared by government practices: reflections for learning. Rev Educ PUC-Camp [Internet]. 2015[cited 2019 Feb 03];20(3):265-77. Available from: https://seer.sis.puc-campinas.edu.br/seer/index.php/reveducacao/article/ download/2803/2206

10. Saldiva PHN, Veras M. Gastos públicos com saúde: breve histórico, situação atual e perspectivas futuras. Estud Av. 2018;32(92):47-61. doi: 10.5935/0103-4014.20180005

11. Medeiros ER, Pinto ESG, Paiva ACS, Nascimento CPA, Rebouças DGC, Silva SYB. Facilities and difficulties in implementing the Health at School Program in a municipality in northeastern Brazil. Rev Cuid. 2018;9(2):2127-34. doi: 10.15649/cuidarte.v9i2.514

12. Medeiros ER, Rebouças DGC, Paiva ACS, Nascimento CPA, Silva SYB, Pinto ESG. Studies evaluating of health interventions at schools: an integrative literature review. Rev Latino-Am Enfermagem. 2018;26:e3008. doi: 10.1590/1518-8345.2463.3008

13. Contandriopoulos A-P. Avaliando a institucionalização da avaliação. Cien Saude Colet. 2006;11(3):705-11. doi: 10.1590/ S1413-81232006000300017

14. Malta M, Cardoso LO, Bastos FI, Magnanini MMF, Silva CMFP. STROBE initiative: guidelines on reporting observational studies. Rev Saude Publica. 2010;44(3):559-65. doi: 10.1590/S0034-89102010000300021

15. Instituto Brasileiro de Geografia e Estatística (IBGE). Brasil, Rio Grande do Norte, Natal [Internet]. Rio de Janeiro (RJ): IBGE; 2020. Available from: https://cidades.ibge.gov.br/brasil/rn/natal/panorama

16. Prefeitura Municipal do Natal (PMN). Saúde. Unidades Municipais de Saúde [Internet]. Natal (RN): PMN; 2020. Available from: https://natal. rn.gov.br/sms/paginas/ctd-180.html

17. Ministério da Saúde (BR). Secretaria de Atenção à Saúde. Departamento de Atenção Básica. Autoavaliação para a Melhoria do Acesso e da Qualidade da Atenção Básica: AMAQ. Brasília (DF): Ministério da Saúde; 2012. 134 p. Available from: http://189.28.128.100/dab/docs/geral/amaq.pdf

18. Donabedian A. Evaluating the Quality of Medical Care. Milbank Q [Internet]. 2005[cited 2019 Feb 03];83(4):691-729. Available from: https:// www.ncbi.nlm.nih.gov/pmc/articles/PMC2690293/pdf/milq0083-0397.pdf

19. Sousa MC, Esperidão MA, Medina MG. A intersetorialidade no Programa Saúde na Escola: avaliação do processo político-gerencial e das práticas de trabalho. Cien Saude Colet. 2017;22(6):1781-90. doi: 10.1590/1413-81232017226.24262016

20. Sousa RR, Trindade R. O impacto da saúde escolar na comunidade educativa. Revista ESC [Internet]. 2013[cited 2019 Feb 03];38:99-116. Available from: https://www.fpce.up.pt/ciie/sites/default/files/07.RitaRamosetal.pdf

21. Storey KE, Montemurro G, Flynn J, Schwartz M, Wright E, Osler J, et al. Essential conditions for the implementation of comprehensive school health to achieve changes in school culture and improvements in health behaviours of students. BMC Public Health. 2016;16(1133):1-11. doi: 10.1186/s12889-016-3787-1

22. Nielsen-Nabe K, Krolner R, Mortensen LH, Jorgensen MB, Diderichsen F. Health promotion in primary and secondary schools in Denmark: time trends and associations with schools' and students' characteristics. BMC Public Health. 2015;15(93):1-10. doi: 10.1186/ s12889-015-1440-z

23. Kuponiyi OT, Amoran OE, Kuponiyi OT. School health services and its practice among public and private primary schools in Western Nigeria. BMC Res Notes. 2016;9(203):1-10. doi: 10.1186/s13104-016-2006-6

24. Hobday K, Ramke J, Toit R, Pereira SM. Healthy eyes in schools: an evaluation of a school and community-based intervention to promote eye health in rural Timor-Leste. Health Educ J. 2015;74(4):392-402. doi: 10.1177/0017896914540896

25. Kirag N, Temel AB. The effect of an eye health promotion program on the health protective behaviors of primary school students. J Educ Health Promot. 2018;7(37):336-42. doi: 10.4103/jehp.jehp_67_17

26. Shrestha RM, Miyaguchi M, Shibanuma A, Khanal A, Yasuoka J, Jimba M. A school health project can uplift the health status of school children in Nepal. PLoS One. 2016;11:e0166001. doi: 10.1371/journal.pone.0166001

27. Kheirouri S, Alizadeh M. Process evaluation of a national school-based iron supplementation program for adolescent girls in Iran. BMC Public Health. 2014;14(959). doi: 10.1186/1471-2458-14-959 
28. Bezerra MA, Carvalho EF, Oliveira JS, Leal VS. Health and nutrition in public and private schools in the city of Recife. Rev Bras Saúde Mater Infant. 2017;17(1):191-200. doi: 10.1590/1806-930420170001000011

29. Oyo-Ita A, Wiysonge CS, Oringanje C, Nwachukwu CE, Oduwole O, Meremikwu MM. Interventions for improving coverage of childhood immunisation in low- and middle-income countries. Cochrane Database Syst Rev. 2016;7:CD008145. doi: 10.1002/14651858.CD008145.pub3

30. Sigaud CHS, Santos BR, Costa P, Toriyama ATM. Promoting oral care in the preschool child: effects of a playful learning intervention. Rev Bras Enferm. 2017;70(3):519-25. doi: 10.1590/0034-7167-2016-0237

31. Kobel S, Wirt T, Schreiber A, Kesztyüs D, Kettner S, Erkelenz N, et al. Intervention Effects of a School-Based Health Promotion Programme on Obesity Related Behavioural Outcomes. J Obes. 2014;ID 476230:1-8. doi: 10.1155/2014/476230 